\title{
Fashioning of Students' Research Competence Through Technology of Project Activities
}

\author{
Sholpan S. Khamzina ${ }^{1, \#,{ }^{*}, \text { Aigul M. Utilova }}{ }^{2, \#}$, Tattigul Zh. Shakenova ${ }^{1, \#,}$ \\ Gulmira A. Suleimenova, ${ }^{3, \#}$ Ella Y. Sarsembayeva, ${ }^{4, \#}$ and Gulomkodir M. Bobizoda ${ }^{5, \#}$ \\ ${ }^{1}$ Department of Environment and Chemical Technologies, Innovative University of Eurasia, Pavlodar, \\ Republic of Kazakhstan \\ ${ }^{2}$ Department of Agriculture and Bioresources, Innovative University of Eurasia, Pavlodar, Republic of \\ Kazakhstan \\ ${ }^{3}$ Department of Pedagogy and Social and Humanitarian Disciplines, Innovative University of Eurasia, \\ Pavlodar, Republic of Kazakhstan \\ ${ }^{4}$ Department of Pedagogy and Psychology, Pavlodar State Pedagogical University, Pavlodar, Republic of \\ Kazakhstan \\ ${ }^{5}$ Academy of Education of the Republic of Tajikistan, Dushanbe, Republic of Tajikistan
}

\begin{abstract}
Objective: The authors provide justifications for changing the current education system, updating the teaching and methodological approach in school specialised education. The paper investigates the issue of fashioning students' research competence through the technology of project activities.

Background: Project activity has become widely used since it combines the theoretical and practical parts of the science under study, which allows to set up a connection between its components. Research competence is an integral feature of a student's personality, which manifests itself in a willingness to take an active research position.

Method: The authors conducted an experiment to study the problem of improving the quality of students' knowledge upon studying biology in senior school. The participants in the experiment were 120 students of the 10th and 11th years of a specialised school for children with psychological disorders.

Results: The authors developed a methodology for the fashioning of research competence. The results of the conducted pedagogical experiment confirmed the validity of the initial assumptions regarding the influence of the use of research teaching methods in biology lessons aimed at improving the quality of biological education.

Conclusion: Through project activities, students with intellectual disabilities learn to work in a team. Despite the fact that teamwork is uniting, each of the students learns to independently set the purpose and tasks of the study, analyse the sources presented, present the results of their activities to others. The main signs of project activity include the fact that students learn the technique and technology of working with the project. Project activity allows for the fashioning of students' research competence during the lesson, thereby enabling students to unleash their potential.
\end{abstract}

Keywords: Educational systems, cognitive skills of students, project technology, educational courses, specialised education.

\section{INTRODUCTION}

In updating the content of education, an important part is played by the functional literacy of students. In terms of training for an updated program, the development of functional literacy is the main goal of education. This means that, as a result of training, functional literacy must be formed in each academic subject. We can verify the maturity and development of functional literacy among students with mental disabilities through tasks of creative content, cognitive, research nature. Tasks of an economic, historical nature, practice-oriented tasks can also help in

*Address correspondence to this author at the Department of Environment and Chemical Technologies, Innovative University of Eurasia, Pavlodar, Republic of Kazakhstan; Tel: +77182673535; E-mail: zh.khamzina@uohk.com.cn

"These authors are equally contributed. determining the formation and development of functional literacy of students. The above indicates that changes occurring in the world and the global economy demand changes in the current education system, i.e. there is a need to update the content of school education, i.e. transition from a knowledge paradigm to a competence one. The issues of the competencebased approach and the fashioning of research competence were covered by scientists from Kazakhstan, Tajikistan, Russia, and other countries.

The problems of the competence-based approach in education were studied by scientists from the Kazakhstan Academy of Education. In their works, scientists [1] provide their custom definition of the concept of "competence". Proceeding from a competence-based approach and investigating the 
content of the concept of "competence", they expressed their opinion on basic and key competencies. According to the presentation of scientists of the Kazakhstan Academy of Education, it is necessary to factor in the readiness of students with intellectual disabilities for adulthood, for solving life problems. Proceeding from this, they determined the willingness of students to fulfil their duties in adult life, to be a citizen of the Republic of Kazakhstan, the desire to continue to receive education throughout their lives as basic competence. The ability of a student with mental disorders to solve problem situations to mobilise their potential opportunities, which include educational, life opportunities, were referred to as key competences. Key competencies include the child's desire to employ its knowledge, skills, and experience to achieve certain goals.

The works of Tajik scientists pay a lot of attention to new methods and forms of the educational process in middle schools, the development of intelligence and creative abilities of students with mental disabilities, which, of course, will contribute to the fashioning of students' research competence. The works of many Tajik scientists-teachers cover certain aspects of the subject matter: M. Gladysheva, Y. Somova, E. llina, A. Kalchenko, A. Koldin, E. Gasanenko, N. Dyorina, T. Kashchenko and G. Yulina [2] and others.

In foreign pedagogics, some matters of fashioning the research competence were investigated in the works of many scientists. Foreign scientists studied aspects such as the organisation of independent activities of students in specialised middle schools for children with psychological disorders; competencybased approach to organising education in a specialised educational school for children with psychological disorders. Even though many scientists investigated the matters of fashioning the students' research competence, some aspects of this issue still remain understudied.

To determine the content of the concept of "research competence", it is necessary to consider the essence of research activity. Currently, there are various approaches to the interpretation of the concept of "research competence", we shall elaborate on some of them:

P. Paidi, I.S. Mercuriani and B. Subali [3] from the standpoint of a systematic approach, consider research competence as a component of professional competence;
From the standpoint of the process and technological approach, A.V. Khutorskoy understands research competence as "the person's possession of appropriate research competence". Under research competence, he suggests understanding knowledge that is the result of a person's cognitive activity in any field of science. In addition, in the content of the concept of "research competence", A.V. Khutorskoy considers methods, research methodologies that a person must master to implement research activities, motivation and researcher's position, their value orientations [4].

In competency-based education, the components of research competence must be consistent with the components of research. V. A. Slastenin shares this opinion. The integrity of theoretical and practical research skills forms a model of students' research competence [5]. Many scientists associate research competence with research activity, i.e. they consider it as the result of properly planned work. For research activities, we can include writing scientific projects, setting up an experiment and analysing its results.

The purpose of the study is to scientifically substantiate and develop a methodology for the fashioning of research competence of students with psychological disabilities within the framework of the subject "Biology".

\section{MATERIALS AND METHODS}

During 2018-2019, authors conducted a pedagogical experiment to study the problem of improving the quality of students' knowledge in the study of biology in grades 10-11. The participants in the experiment were 120 students of the 10th and 11th years of the specialised school No. 15 for children with psychological disorders in Pavlodar, Republic of Kazakhstan. The fashioning of research competence constitutes an entire methodological system. It is constructed at two levels: theoretical-methodological and curricular. At the first level, the fashioning of research competence was carried out in the course of the research activities of students. At the second level, the target, substantive, procedural, technological, and result-evaluative components are integrated. On this basis, the authors developed a methodology for the fashioning of research competence.

Within the framework of the subject "Biology", elective courses help students with mental disease 
learn about the most important ways and methods of applying knowledge in practice, building an individual educational path, developing their interests, and career-oriented aspirations.

The course "Methodology of scientific research in biology" is focused on developing the ability of high school students to carry out personal self-education, to design a further educational route and a professional career in the field of such a science as biology. The course content is also aimed at the fashioning of students' research competence, which will allow students to master the methods of scientific research in the field of biology. Proceeding from this, we can say that project activity is the field of teaching methods used within the framework of a particular subject.

The basis of project activity underlies the development of creative and critical thinking, cognitive skills of students with psychological disabilities, the ability to apply the acquired knowledge and skills upon solving specific problems, or, in other words, is the path of knowledge development. Accordingly, project activity is a way to achieve a didactic goal through the development of a problem, complete with a certain result. The project activity is focused on the independent work of students (individual, work in pairs, in groups), who perform it within a certain period. The solution to the problem, on the one hand, lies in the use of various methods and means of training, on the other hand - in the use of knowledge, skills and abilities, and understanding of how to apply them.

Independence in project activities concerns not only the setting of goals and aims, decision-making but also the implementation of the project itself. Students with intellectual disabilities should command creative (transform various ideas, find several ways to solve the problem, predict the consequences of the decision made), communicative (the ability to listen and hear the interlocutor, conduct a discussion, clearly state their thoughts, give arguments in favour of resolving the problem, etc.), intellectual (summarise, draw conclusions, work with text, etc.) skills [6].

Depending on the problem, the subjects of projects may vary. It can be of a theoretical nature, to deepen any material, or practical, requiring knowledge of not just one science, but from different disciplines, thereby developing research skills and creative thinking. Therefore, the integration of acquired knowledge occurs. The results of the completed project activities should be provided in the form of a presentation, publication, etc. Comprehension of project activities is of foremost importance for the fashioning of students' thought process (a source of new knowledge, activation of students' creative abilities, intellectual development).

\section{RESULTS}

To assess the maturity of research competence, competence tasks were developed. Applying the element-by-operation analysis of students' activities in educational situations, the authors verified the levels of maturity of research competence. The study assessed the ability to use biological knowledge in life situations; the ability to identify questions that can be answered with the use of biological knowledge; the ability to draw conclusions, argue personal opinion; the ability to analyse the data of the study.

The maturity of the research competence of students with psychological disorders in the process of studying the elective course or the implementation of the project can be estimated by means of the scale for assessing the level of the fashioning of students' research competence. Proceeding from the contents of Table 1, we can estimate the maturity students' research competence at the following levels: high, medium, low.

The scale for assessing the maturity of students' research competence helps to identify the maturity of specific research competence (Table 2).

Table 1: The Scale of Assessment of the Maturity of Students' Research Competence

\begin{tabular}{|c|c|c|}
\hline Level & Level grade score & Level description \\
\hline \hline High & 3 & $\begin{array}{c}\text { Students obtain high results in carrying out research activities and have mature } \\
\text { research competence. }\end{array}$ \\
\hline Medium & 2 & $\begin{array}{c}\text { Students situationally obtain high results in the process of carrying out research } \\
\text { activities. In some cases, there may be a gap in operations, such as the } \\
\text { performance of certain actions. }\end{array}$ \\
\hline Low & 1 & $\begin{array}{c}\text { Students show that they have frequent and ongoing difficulties in performing } \\
\text { research activities. They have insufficiently formed research competences. }\end{array}$ \\
\hline
\end{tabular}


Table 2: Data on the Levels of Specific Research Competence

\begin{tabular}{|c|r|c|}
\hline No. & Research competences & Research competence Levels \\
\hline \hline 1 & Ability to analyse and synthesise & High, medium, low \\
\hline 2 & Ability to use methodological concepts & High, medium, low \\
\hline 3 & Ability to correctly use various research methods & High, medium, low \\
\hline 4 & Ability to correctly carry out various research procedures & High, medium, low \\
\hline 5 & Ability to think critically & High, medium, low \\
\hline 6 & Research focus & High, medium, low \\
\hline 7 & Ability to use information technology & High, medium, low \\
\hline 8 & Ability to collaborate with different participants & High, medium, low \\
\hline 9 & Ability to work productively in a team & \\
\hline
\end{tabular}

From the standpoint of teaching methods, the result of project activities is defined as certain competencies and skills mastered by students with intellectual disabilities. By carrying out interesting, and at the same time relevant projects, schoolchildren find an application of the acquired knowledge, skills in practical activities, learn to work with the presented information, for example, upon working with a scientific paper in a journal or collection, selecting the relevant material for the project, working with a bibliographic catalogue, etc.

The results of the conducted pedagogical experiment confirmed the validity of the initial assumptions regarding the influence of the use of research teaching methods in biology lessons aimed at improving the quality of biological education. The level of knowledge acquired by students increased by $13.24 \%$ (at the intermediate stage - by $8.98 \%$ ). The average efficiency of the volume of assimilated material in the intermediate testing was $4.7 \%$, in the final testing $-8.6 \%$.

\section{DISCUSSION}

Design technology as a global problem uniting the social, personal, cultural principles in the life of a particular person was reflected in the works of the following scientists: V.P. Bespalko [6], V.I. Zagvyazinsky [7], B.T. Likhachev [8], V.A. Slastenin [5] and others. Problems of project activities from a pedagogical standpoint are considered in the works of M.N. Artseva [9], O.V. Berezhnaya and N.Z. Smirnova [10] and others. According to the abovementioned researchers, project activity is a flexible model for the organisation of the educational process, focused on personal fulfilment of students' personality, the development of intellectual capabilities, creative abilities in the process of implementing a scientific project within the framework of studying the subject.

The technology of project activities can also be used in conducting elective courses. Elective courses can also aid in developing students' research competence. Elective courses should be provided in an amount that allows the student to make a real choice. Courses should help students with mental disorders assess their potential in terms of educational perspectives [11, 12]. Courses should help to create positive motivation for learning on the planned profile. Upon determining the content, they should determine the usefulness of this course for the student with regards to making an informed choice of the profile of education in high school. As a result of studying elective courses, the student should be ready to answer two questions: "What do I want in my immediate educational future?" and "Can I, am I ready to continue training in the chosen direction?".

The courses should help students with psychological disabilities learn about the specific types of activities that will be leading for them should they make a choice (biologist, historian, philologist, economist, designer, etc.) $[13,14]$. That is, they should influence the choice of a student in the field of professional activity.

\section{CONCLUSIONS}

Through project activities, students with intellectual disabilities learn to work in a team. Such a quality as tolerance towards each other is manifested. Students learn to work in groups, in pairs, and individually. Despite the fact that teamwork is uniting, each of the students learns to independently set the purpose and tasks of the study, analyse the sources presented, 
present the results of their activities to others. Today, project activity is considered the technology of the $21 \mathrm{st}$ century, as it is conducive to meeting the requirements of the educational process in specialised middle schools for children with psychological disorders, including the achievement by students of relevant knowledge, skills, and abilities.

The main signs of project activity include the fact that students learn the technique and technology of working with the project. Further, they perform analysis, learn to predict, and plan their activities. The advantages of project activities are that students with mental disorders learn to work independently since this method of work involves the individual participation of each student with psychological disabilities in the learning process of a school subject. Project activity allows for the fashioning of students' research competence during the lesson, thereby enabling students to unleash their potential.

\section{ACKNOWLEDGEMENT}

None.

\section{REFERENCES}

[1] Kurbanbekov BA, Turmambekov TA, Baizak UA, Saidakhmetov PA, Abdraimov RT, Bekayeva AE, Orazbayeva KO. Students' experimental research competences in the study of physics. International Journal of Environmental and Science Education 2016; 11(18): 1306913078.

[2] Gladysheva M, Somova Y, llina E, Kalchenko A, Koldin A, Gasanenko E, Dyorina N, Kashchenko T, Yulina G. Results of experimental work at different stages of continuous education for estimation of the formation of research competences of students. Journal of Advanced Research in
Dynamical and Control Systems 2019; 11(9 Special Issue): 569-574.

https://doi.org/10.5373/JARDCS/V11/20192606

[3] Paidi P, Mercuriani IS, Subali B. Students' competence in cognitive process and knowledge in biology based on curriculum used in Indonesia. International Journal of Instruction 2020; 13(3): 491-510. https://doi.org/10.29333/iji.2020.13334a

[4] Khutorskoy AV. (Ed.). Competences in education: design experience. Moscow: Research and Development Enterprise "INEC" 2007.

[5] Slastenin VA, Isaev IF, Mishchenko Al, Shiyanov EN. Pedagogics. Moscow: Shkola-Press, 1998.

[6] Bespalko VP. Components of pedagogical technology. Moscow: Prosveshcheniye, 1989.

[7] Zagvyazinsky VI. Practical methodology of pedagogical search. Tyumen: Publishing House ZAO Legion-Group, 2005.

[8] Likhachev BT. Methodological fundamentals of pedagogics. Samara: Publishing House of Samara Management Institute, 1998.

[9] Artseva MN. Educational research work of students Methodological recommendations for students and teachers. Head Teacher 2005; 6: 4-29.

[10] Berezhnaya OV, Smirnova NZ. Organisation of a research lesson in biology at school. Biology at School 2014; 2: 26-29.

[11] Ahiri J, Dunifa L, Tanduklangi T, Ghani ARA. The effect of learning strategies on higher-order thinking skills students with different learning. International Journal of Science and Research 2015; 4(9): 1204-1211.

[12] Howarth S, Slingsby D. Biology fieldwork in school grounds: A model of good practice in teaching science. School Science Review 2006; 87(320): 99-105.

[13] Paidi D, Yulaikah S, Alfindasari D. Development of instrument to assess cognitive process and knowledge in biology senior high school. International Journal of Environmental and Science Education 2017; 12(8): 17191735.

[14] Zhuravleva NA, Shkerina LV. Basic principles and didactic conditions for the formation of basic key competencies of students-future teachers of mathematics. Bulletin of the Krasnoyarsk State Pedagogical University named after V.P. Astafiev 2011; 4(18): 30-35.

\section{DOI: https://doi.org/10.6000/2292-2598.2020.08.03.6}

(C) 2020 Khamzina et al.; Licensee Lifescience Global.

This is an open access article licensed under the terms of the Creative Commons Attribution Non-Commercial License (http://creativecommons.org/licenses/by-nc/3.0/) which permits unrestricted, non-commercial use, distribution and reproduction in any medium, provided the work is properly cited. 